Doi: $\underline{\text { dx.doi.org/10.17921/2525-5320.2016.164-166 }}$

\title{
PROFESSORES COM DEFICIÊNCIA QUE TRABALHAM O ENSINO DE ARTE NO MUNICÍPIO DE LONDRINA: UMA ANÁLISE DO CENSO ESCOLAR
}

Taísa Grasiela Liduenha Gonçalves* - UNOPAR

Palavras-chave: Professores com Deficiência. Arte. Censo Escolar.

\section{INTRODUÇÃO}

O censo escolar da educação básica do Instituto Nacional de Estudos e Pesquisas Educacionais Anísio Teixeira (INEP), desde 2012, apresenta dados sobre professores com deficiência. Ao entrelaçar os temas: Arte, professor e deficiência protagonizamos professores deficientes como interlocutores de suas práticas pedagógicas em Arte através de entrevista semiestruturada. Barroco e Superti (2014) mostram as contribuições da Arte para o desenvolvimento humano com base na psicologia histórico-cultural, assim como a pedagogia histórico crítica, que inicialmente, fundamentou a Diretrizes Curriculares do Paraná (PARANA, 2008). Ao analisar o banco de teses e dissertações da Comissão de Aperfeiçoamento de Pessoal do Nível Superior (CAPES) e da Biblioteca Digital Brasileira de Teses e Dissertações (BDTD) de 1981 a 2014 constatou-se que não há produção sobre professor com deficiência na Educação Básica demonstrando carência de pesquisas nesta área.

Caracterizar os professores com deficiência que trabalham com Arte na rede pública de ensino do município de Londrina e apresentar algumas concepções desses sujeitos a partir da interface: arte e deficiência por meio de informações obtidas em entrevistas.

\section{MATERIAL E MÉTODOS}

Com as políticas de Inclusão há um incremento das matrículas de alunos com necessidades educacionais especiais (NEE) nas escolas brasileiras (BUENO; MELETTI, 2011). Estudos sobre esse assunto são recentes e o foco ainda se 
encontra na formação docente para a inclusão desses alunos. Em estudo dos microdados de 2014, disponibilizados no censo escolar da Educação Básica, do INEP com base no software IBM SPSS (Statistical Package for the Social Sciences) para leitura e tratamento estatístico percebemos um número significativo de docentes com NEE. Consideramos esses professores exitosos em seu percurso discente e suas presenças personificam as políticas de inclusão justificando a necessidade de estudo sobre quem são, quais suas necessidades e as expectativas profissionais. Essa inclusão realmente vem acontecendo? Ou esses professores estão na contramão da realidade vigente? Foram realizadas entrevistas com os docentes localizados pelos microdados. Este estudo vem sendo realizado desde 2015.

\section{RESULTADOS E DISCUSSÃO}

Foram localizadas cinco docentes com deficiência, do sexo feminino, que trabalham Arte no município de Londrina. Destas, duas apresentam deficiência física; duas baixa visão e uma surdez. Verificou-se que no Ensino Médio quatro professoras fizeram o magistério. Na licenciatura: uma fez Pedagogia à distância (EAD) e duas presencial, duas fizeram Normal Superior EAD (uma delas complementou para Pedagogia), uma fez Arte. Na formação continuada: uma fez o Plano Nacional de Formação de Professores da Educação Básica (PARFOR) em Música; três fizeram especialização. Outro dado é que em um período da carga horária de trabalho todas as professoras lecionam no ensino fundamental e no outro período, uma trabalha no Ensino Médio; uma na Educação Infantil e uma trabalha na coordenação pedagógica. No que se refere à interface da educação especial e a Arte, duas professoras mencionaram, nas entrevistas que, não tiveram conhecimentos sobre o ensino de Arte no magistério e três indicaram a falta desses conhecimentos no curso de Pedagogia, deste modo, não se sentem à vontade para trabalhar com experiências estésicas e estéticas, teoria e história da Arte com alunos com e sem deficiência.

\section{CONCLUSÃO}


Conclui-se que apenas uma professora apresenta formação específica em Arte e esta trabalha em uma escola estadual. As outras quatro professoras trabalham na dependência administrativa municipal e apresentam formação inicial e continuada insuficiente em Arte, utilizando-se da Arte como apoio a outras disciplinas e em datas comemorativas. Sobre a Arte para os alunos, com deficiência e sem deficiência, as professoras indicaram a falta de espaço físico, de materiais e adaptações nas escolas.

\section{REFERÊNCIAS}

BARROCO, S.M.S.; SUPERTI, T. Vigotski e o estudo da Psicologia da Arte: contribuições para o desenvolvimento humano. Psicol. Soc., v.26, p.22-31, 2014.

BRASIL. Ministério da Educação. Instituto Nacional de Estudos e Pesquisas Educacionais Anísio Teixeira - INEP. Censo Escolar da Educação Básica - 2014.

MELETTI, S.M.F.; BUENO, J.G.S. O impacto das políticas públicas de escolarização de alunos com deficiência: uma análise dos indicadores sociais no Brasil. Linhas Críticas, v.17, p.367-384, 2011.

PARANÁ, Secretaria de Estado da Educação. Diretrizes Curriculares da Educação Básica. Curitiba: SEED, 2008. 